\title{
Comparative Study Of Using Sea-Water For Enhanced Oil Recovery In Carbonate And Sandstone Reservoirs: Effects of Temperature and Aging Time on Oil Recovery
}

\author{
Madi Naser ${ }^{*}$, Mohamed Erhayem ${ }^{2}$, Ali Hegaig ${ }^{3}$, Hesham Abdullaha $^{1}$, Muammer Amera ${ }^{1}$, Abdalsalam Mohameda $^{1}$ \\ ${ }^{1}$ Petroleum Engineering of Faculty of Mining and Energy, Sebha University, Libya \\ ${ }^{2}$ Chemistry department, Faculty of Science, Sebha University, Libya \\ ${ }^{3}$ Mechanical Engineering, Faculty of Engineering, Misurata University, Libya
}

\begin{abstract}
Oil recovery process is an essential element in the oil industry, in this study, a laboratory study to investigate the effect of temperature and aging time on oil recovery and understand some of the mechanisms of seawater in the injection process. In order to do that, the sandstone and carbonate cores were placed in the oven in brine to simulate realistic reservoir conditions. Then, they were aged in crude oil in the oven. After that, they were put in the seawater to recover, and this test is called a spontaneous imbibition test. The spontaneous imbibition test in this study was performed at room temperature to oven temperature $80{ }^{\circ} \mathrm{C}$ with different sandstone and carbonate rock with aging time of 1126 hours. The result shows that the impact of seawater on oil recovery in sandstone is higher than carbonate. At higher temperature, the oil recovery is more moderate than low temperature. Likewise, as the aging time increase for both sandstone and carbonate rocks the oil recovery increase.
\end{abstract}

Keywords: Carbonate, Sandstone, Oil Recovery, Aging Time, Temperature, Spontaneous Imbibition Test.

* Coresponding author: Mad.Abdullah@sebhau.edu.ly

\section{INTRODUCTION}

Normally, only $5-30 \%$ of the original oil in place (OOIP) can be produced by the native pressure energy stored in the reservoir (Castor et al., 1981) and (Farouq-Ali and Stahl, 1970). This phase of the production cycle is called the primary production period. The water-flooding method discovered nearly by accident in 1870 , (Schumacher, 1978). This was increased the oil production to a total recovery of 40-60\% of OOIP, which is called the secondary production period. Secondary production mentions to procedures, such as gas or water injection, (Naser et al., 2013). During the water-flooding period, oil is produced at a steady state with increasing water-oil ratio at the production wells. When the water-oil ration has become too high, oil cannot be produced in a cost effective way anymore and the field has reached the economical limit. At this point, about 40-60\% of OOIP is left in reservoir, mainly because of unfavourable wettability conditions, heterogeneous rock properties (fractures, layers with large permeability contrasts, impermeable layers) and capillary trapped-and bypassed oil. Wettability is very important parameter in oil recovery processes, because it has strong impacts on distribution, location and flow of oil and water in the reservoir during production, (Anderson, 1987b, 1987c; Anderson, 1986a; Anderson, 1986b, 1987a; Cuiec, 1975). Water will occupy the narrowest pores and oil will reside as small droplets in the middle of the pores in uniform water-wet system. The reserve fluid distribution will be the case in an oil-wet reservoir. The residual oil is left in the reservoir after the secondary oil production stage, which is the target for enhanced oil recovery (EOR) processes. EOR define is the methods aimed at increasing ultimate oil recovery by injecting agents not normally present in the reservoir, such as chemicals, solvents, oxidizers and heat carriers in order to induce new mechanisms for displacing oil, (Bavière, 1991).

A number of research works have been investigated of the effect of brine concentration on oil recovery often showed significant increase in laboratory water-flood recoveries with a decrease in salinity for duplicate outcrop core plugs. However, companion data sets for water-floods and spontaneous imbibition both showed increased recovery with a decrease in salinity, (Tang and Morrow, 1999a; Tang and Morrow, 1999b; Tang and Morrow, 2002; Zhang and Morrow, 2006). The studies shows that, the effect of temperature on oil recovery oil 
production rate increase or decrease with temperature, which the viscosity of oil, reduce due the increase of temperature. Therefore, the decrease in the viscosity ratio of oil and water due to increasing temperature result in oil being displaced more easily and the ultimate recovery being improved. Aging time is required to incubate the core samples, however, varies from one laboratory to another, ranging from a few days to months, (Mungan, 1972; Wissmann, 1963), (Wendell et al., 1987), (Cuiec, 1975; Culec, 1977). Naser investigated the effects of temperature, hardness, surfactants and alkaline on oil recovery from carbonate reservoirs using spontaneous imbibition tests. The spontaneous imbibition test in this study was performed at $25^{\circ} \mathrm{C}$ and $80^{\circ} \mathrm{C}$ with different limestone rocks. The results show that, at high temperature, the oil recovery is higher than at low temperature. The hardness has various impacts on the wetting properties. $\mathrm{SO}_{-}{ }_{4}^{2}$ and $\mathrm{Ca}^{2+}$ are important in changing wettability on limestone surface and were proved by increase in oil recovery. $\mathrm{Mg}^{2+}$ ion effects were demonstrated by the very small increase in oil recovery, (Naser, 2014).

This paper has two main objectives. The first objective is to investigate the effect of temperature and aging time on oil recovery and understand some of the mechanisms of seawater in the injection process. The second objective is to compare the effects of seawater on carbonate and sandstone reservoirs related to chemical enhanced oil recovery. Three commercial crude oil located in X Oil Field and (18) eighteen sandstone and carbonate cores were used. For this purpose, the parameters that have been considered for this study are carbonate, sandstone, oil recovery, aging time, and temperature. Experiments presented in this study were run at an elevated temperature $(27,30,40,50,60,70 \text {, and } 80)^{\circ} \mathrm{C}$ conditions. Afterwards, a sandstone and carbonate sample is chosen and saturated with oil. The oil-saturated sample is then placed in an imbibition cell surrounded by seawater. The seawater is allowed to imbibe into the core sample displacing oil out of the sample until equilibrium is reached. The volume of oil displaced is measured directly or determined by weight measurements and the oil recovery is determined.

\section{MATERIALS AND METHODS}

\section{Spontaneous Imbibition Test}

The spontaneous imbibition Amott test consists the placing oil saturated in core plug, which the Amott cell is filled with displaced fluid with sea-water. The oil expelled from the core can be measured accurately by reading the graduation on the top of the cell. Graduated cylinder was used to simulate the operation of imbibition cell (Amott cell).

\section{Oil Samples}

Figure 1 shows the three types of oils from Hamada Field-V32 and V2, Jakhira Field-GSOP. The analysis of composition of oil done at petroleum institute in Tripoli, Libya as listed in Table 1. Sea-water samples used in this study were collected from Tajora-Tripoli, Libya.

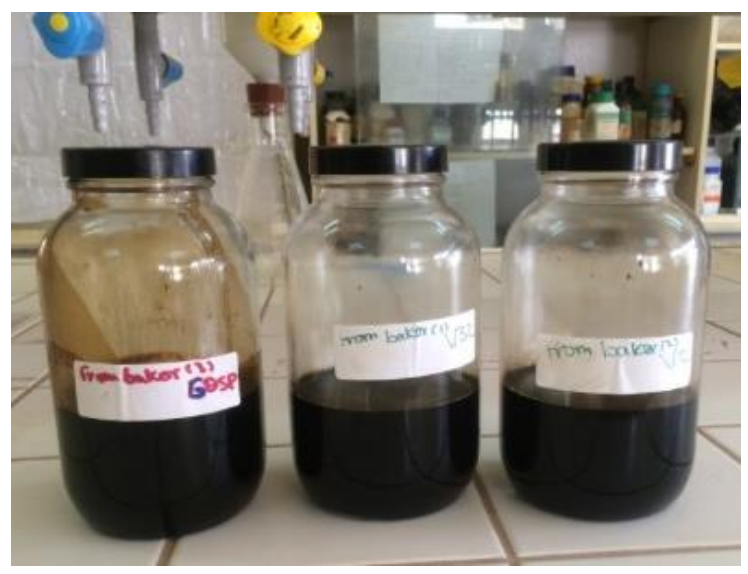

Fig. 1. Oil samples used in this study. 
Table 1. Oil composition used in this study.

\begin{tabular}{|c|c|c|c|}
\hline \multirow[t]{2}{*}{ Component } & Hamada field V32 & Hamada field V2 & Jakhira field-GSOP \\
\hline & $\begin{array}{c}\text { Flashed Liquid } \\
\text { Mole\% }\end{array}$ & $\begin{array}{c}\text { Flashed Liquid } \\
\text { Mole\% }\end{array}$ & $\begin{array}{c}\text { Flashed Liquid } \\
\text { Mole\% }\end{array}$ \\
\hline Hexane & 3.24 & 3.99 & 2.92 \\
\hline Heptane & 6.94 & 8.08 & 3.45 \\
\hline Octane & 13.53 & 14.71 & 6.27 \\
\hline Nonane & 12.38 & 12.74 & 6.54 \\
\hline Decane & 11.05 & 10.69 & 6.44 \\
\hline n-Undecane & 8.78 & 8.81 & 6.44 \\
\hline n-Dodecanes & 6.83 & 7.15 & 5.78 \\
\hline n-Tridecanes & 6.87 & 6.88 & 6.93 \\
\hline n-Tetradecanes & 4.80 & 4.70 & 5.89 \\
\hline n-Pentadecanes & 4.17 & 4.05 & 6.11 \\
\hline n-Hexadecanes & 3.05 & 2.89 & 4.76 \\
\hline n-Heptadecanes & 3.04 & 2.72 & 4.69 \\
\hline n-Octadecanes & 2.76 & 2.52 & 4.90 \\
\hline n-Nonadecanes & 2.48 & 2.30 & 4.48 \\
\hline n-Eicosane & 1.59 & 1.41 & 3.39 \\
\hline n-Heneicosane & 1.46 & 1.31 & 3.34 \\
\hline n-Docosane & 1.32 & 1.19 & 2.92 \\
\hline n-Tricosane & 0.99 & 0.89 & 2.66 \\
\hline n-Tetracosane & 0.89 & 0.74 & 2.18 \\
\hline n-Pentacosane & 0.74 & 0.60 & 1.90 \\
\hline n-Hexacosane & 0.66 & 0.53 & 1.58 \\
\hline n-Heptacosane & 0.59 & 0.46 & 1.55 \\
\hline n-Octacosane & 0.50 & 0.36 & 1.21 \\
\hline n-Nonacosane & 0.31 & 0.26 & 1.11 \\
\hline n-Triacontane & 0.25 & - & 0.69 \\
\hline n-Hentriacontane & 0.24 & - & 0.66 \\
\hline n-Dotriacontane & 0.22 & - & 0.45 \\
\hline n-Tritriacontane & 0.18 & - & 0.33 \\
\hline n-Tetratriacontane & 0.13 & - & 0.24 \\
\hline n-Pentatriacontane plus & - & - & 0.20 \\
\hline
\end{tabular}

\section{Collection of Core Samples}

The core samples were collected from the deep water well in Temnhent, north of Sebha City, Sebha State, Libya. Figure 2 shows the core cutting processing. The cores were cut with uniform cylindrical shape and the volume of cores were correctly estimated. All cores have height between $(4.2$ to $4.9 \mathrm{~cm})$ and diameter around $(2.45 \mathrm{~cm})$. 


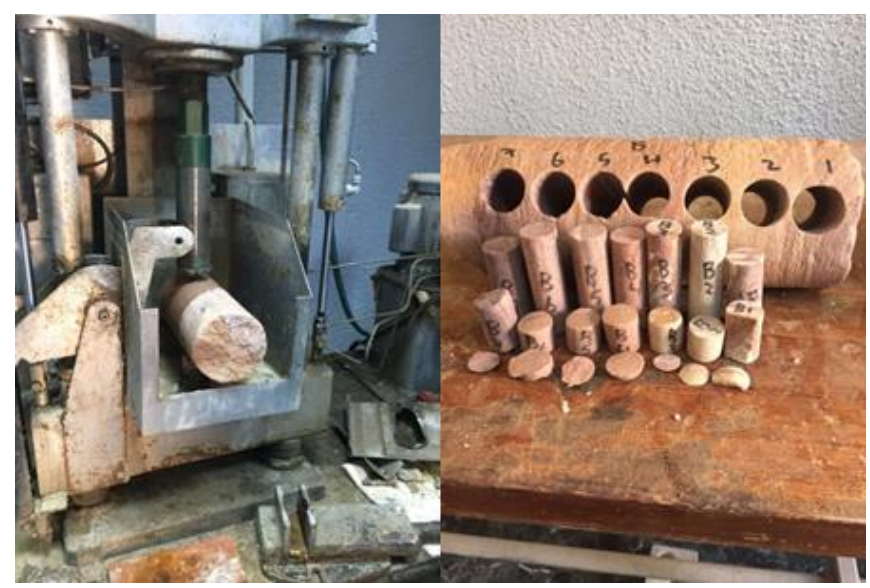

Fig. 2. Process of cut core sample $\&$ shape of cores after cut process.

The cores were cleaned and washed by using distillate water and were put in the oven with $70^{\circ} \mathrm{C}$. The dry core samples weight were measured until the constant weight was obtained. Then, the core samples were put in the vacuum chamber with known density of brine solution (with $3 \%$ of $\left(\mathrm{NaCl}_{2}\right)$ ) for at least $24 \mathrm{hrs}$, and the weight of the core samples were measured. The porosity was also calculated.

\section{Core Aging}

The cores were put in different oils inside the oven for eleven days with $70^{\circ} \mathrm{C}$ and then placed in the vacuum chamber for $4 \mathrm{hrs}$, to ensure the core samples are saturated with $100 \%$ of oil. The core sample were saturated with different of oils, then their weight were measured.

\section{Original Oil in Place Calculation (OOIP)}

The calculation of OOIP is done by using following equation:

$$
O O I P=\frac{W_{1}-W_{2}}{D}
$$

Where: $\mathrm{W}_{1}=$ weight of core sample saturated, $\mathrm{W}_{2}=$ weight of core sample dry and $\mathrm{D}=$ density of saturated oil.

\section{Spontaneous Imbibition Test}

The core samples were placed in the in imbibition cell, which were filled with the sea-water and close it with filler and para film at room temperature. The sea-water was allowed to imbibe into the cores displacing oil out of the cores until equilibrium was reached. The volume of oil displaced by seawater was measured directly for each $2 \mathrm{hrs}$. The spontaneous imbibition test was repeated at different temperature $30,40,50,60,70$, and $80^{\circ} \mathrm{C}$. It was noted that the oil production inside the tube was evaporated at $80^{\circ} \mathrm{C}$, which require to lowering the oven temperature to $70^{\circ} \mathrm{C}$.

\section{RESULTS AND DISCUSSIONS}

\section{Porosity and OOIP Result:}

The properties of core samples were listed in Table 2. 
Table 2. Porosity and OOIP results.

\begin{tabular}{|c|c|c|c|c|}
\hline Name of sample & $\begin{array}{l}\text { Original oil in place } \\
\text { (OOIP) }\end{array}$ & $\begin{array}{l}\text { Bulk volume } \\
\text { (ml) }\end{array}$ & Pore volume (ml) & $\begin{array}{c}\text { Porosity } \\
(\%)\end{array}$ \\
\hline S301 (V2) & 8.5871 & 28.4706 & 7.7611 & 27.26 \\
\hline S304 (GSOP) & 11.6146 & 35.3429 & 10.105 & 28.591 \\
\hline S305 (GSOP) & 11.2908 & 36.8155 & 9.8907 & 26.865 \\
\hline S306 (GSOP) & 12.3241 & 35.3429 & 10.5881 & 29.658 \\
\hline S308 (V32) & 11.5289 & 37.7972 & 10.479 & 27.724 \\
\hline S312 (V32) & 12.2476 & 39.2669 & 10.7683 & 27.423 \\
\hline S313 (V32) & 11.4029 & 37.7972 & 10.0385 & 26.558 \\
\hline S314 (V2) & 11.0809 & 32.8885 & 9.7685 & 29.701 \\
\hline S315 (V2) & 9.1532 & 28.9615 & 8.0789 & 27.895 \\
\hline C401 (V32) & 10.6061 & 33.8702 & 9.3698 & 27.663 \\
\hline C402 (V32) & 10.3602 & 35.2938 & 9.098 & 25.777 \\
\hline C403 (V32) & 13.2458 & 37.3064 & 11.6927 & 31.342 \\
\hline C404 (V2) & 8.5521 & 34.3611 & 7.539 & 21.94 \\
\hline C405 (V2) & 8.8505 & 31.9068 & 7.6759 & 24.057 \\
\hline C406 (V2) & 9.1881 & 33.3794 & 8.3008 & 24.868 \\
\hline C408 (GSOP) & 6.9482 & 23.071 & 6.0929 & 26.409 \\
\hline C410 (GSOP) & 14.1313 & 22.0893 & 6.7586 & 30.596 \\
\hline C411 (GSOP) & 7.4168 & 24.0528 & 5.4792 & 22.779 \\
\hline
\end{tabular}

\section{Spontaneous Imbibition Test Results}

\section{Carbonate Rock Samples aged in Jakhira Field- GSOP Oil Results}

The carbonate Rock Samples were aged in Jakhira Field- GSOP Oil as shown in the Figure 3. The effect of temperature on recovery was reported.

Room Temperature $27^{\circ} \mathrm{C}$ : After $22 \mathrm{hrs,} \mathrm{the} \mathrm{oil} \mathrm{recovery} \mathrm{rate} \mathrm{was} \mathrm{about} 1.21 \%$, while the cores, C408 and 410, had no recovery rates yet. At $48 \mathrm{hrs}$, the oil recovery for the core $\mathrm{C} 410$ was $1.41 \%$, and for C408 the oil recovery was $0.2 \%$ at $115 \mathrm{hrs}$.

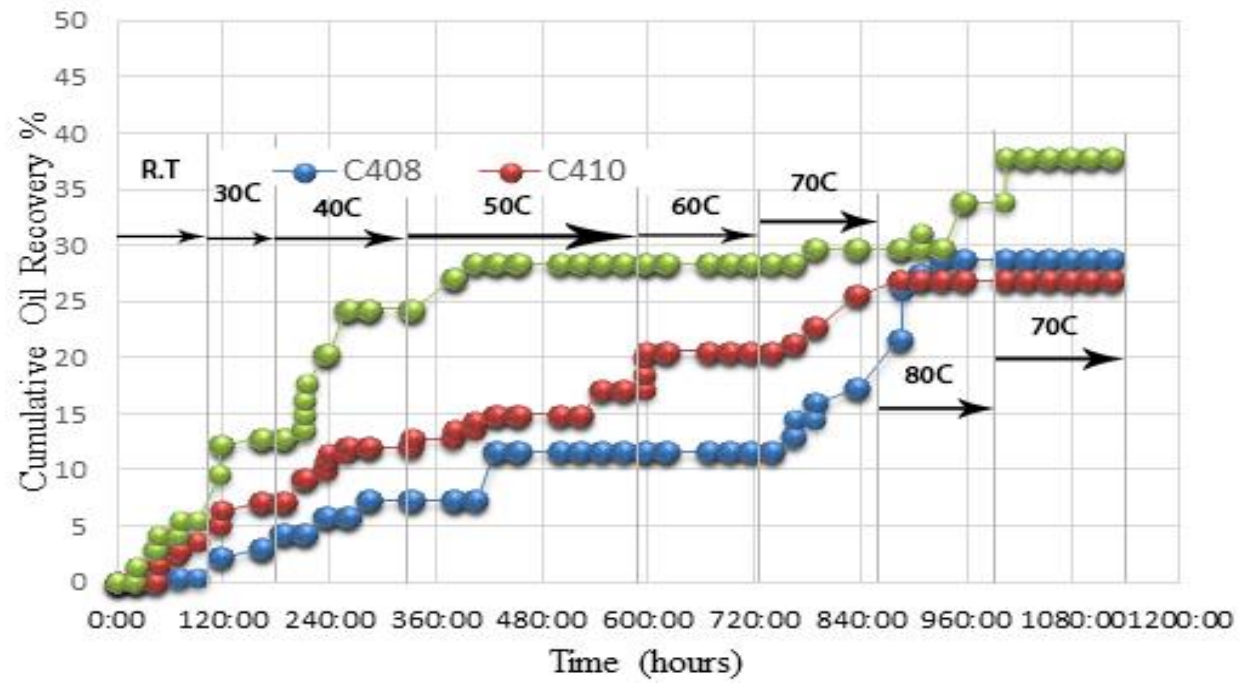

Fig. 3. Cumulative oil recovery in carbonate aged in Jakhira Field- GSOP Oil.

Oven Temperature $3^{\circ} \mathrm{C}$ : At $162 \mathrm{hrs}$, the cumulative oil recovery rate increase spontaneously in $\mathrm{C} 408$ to reached $2.87 \%$ and $\mathrm{C} 411$ to reach $12.80 \%$ at $30^{\circ} \mathrm{C}$. While the oil recovery rate for $\mathrm{C} 410$ was still stable 
with $7.07 \%$. At $188 \mathrm{hrs}$, the core $\mathrm{C} 408$ was produced with mini bubbles of oil till the oil recovery was $4.31 \%$.

Oven Temperature $4^{\circ} \mathrm{C}$ : At $210 \mathrm{hrs}$, the $\mathrm{C} 410$ was slightly increased to $9.19 \%$, and $13.48 \%$ in $\mathrm{C} 411$ at 330 hrs,.

Oven Temperature $\mathbf{5 0}^{\circ} \mathbf{C}$; At $263 \mathrm{hrs}$, the oil rate for $\mathrm{C} 410$ and $\mathrm{C} 411$ have increased to $12.03 \%$ and $24.26 \%$, respectively. While the $\mathrm{C} 408$ had no change in cumulative oil recovery.

Oven Temperature $\left(\mathbf{6 0}^{\circ} \mathbf{C}\right)$ : In the first $\mathrm{hr}$, the oil recovery core in $\mathrm{C} 410$ was increased to $18.39 \%$ with continues increase till $20.52 \%$. In cores $\mathrm{C} 408-\mathrm{C} 411$ oil rate were stable and no significant change was noted.

Oven Temperature $\left(\mathbf{7 0}^{\circ} \mathbf{C}\right)$ : at $766 \mathrm{hrs}$, the oil recovery increased to reach $14.39 \%$ in $\mathrm{C} 408$, and $21.22 \%$ in C410, and $28.31 \%$ in C411. At 838 hrs, the oil recovery increased till $17.27 \%$ in C408, and $25.47 \%$ in C410, and 29.66\% in C411. At 1005 hrs, the oil recovery increased in C411 to reach $37.75 \%$ until 1126 hrs, the oil recovery was stable.

Oven Temperature $\left(\mathbf{8 0}^{\circ} \mathbf{C}\right)$ : at $955 \mathrm{hrs}$, the oil recovery increased to reach $28.78 \%$ in $\mathrm{C} 408$, and $26.89 \%$ in $\mathrm{C} 410$, and $33.70 \%$ in $\mathrm{C} 411$. At $80^{\circ} \mathrm{C}$, the laboratory problem was required to lowering the temperature of the oven to $70^{\circ} \mathrm{C}$.

\section{Sandstone Rock Samples aged in Jakhira Field-GSOP Oil Results}

The sandstone rock samples were aged in Jakhira Field-GSOP Oil as shown in the Figure 4. The effect of temperature on the oil recovery was reported.

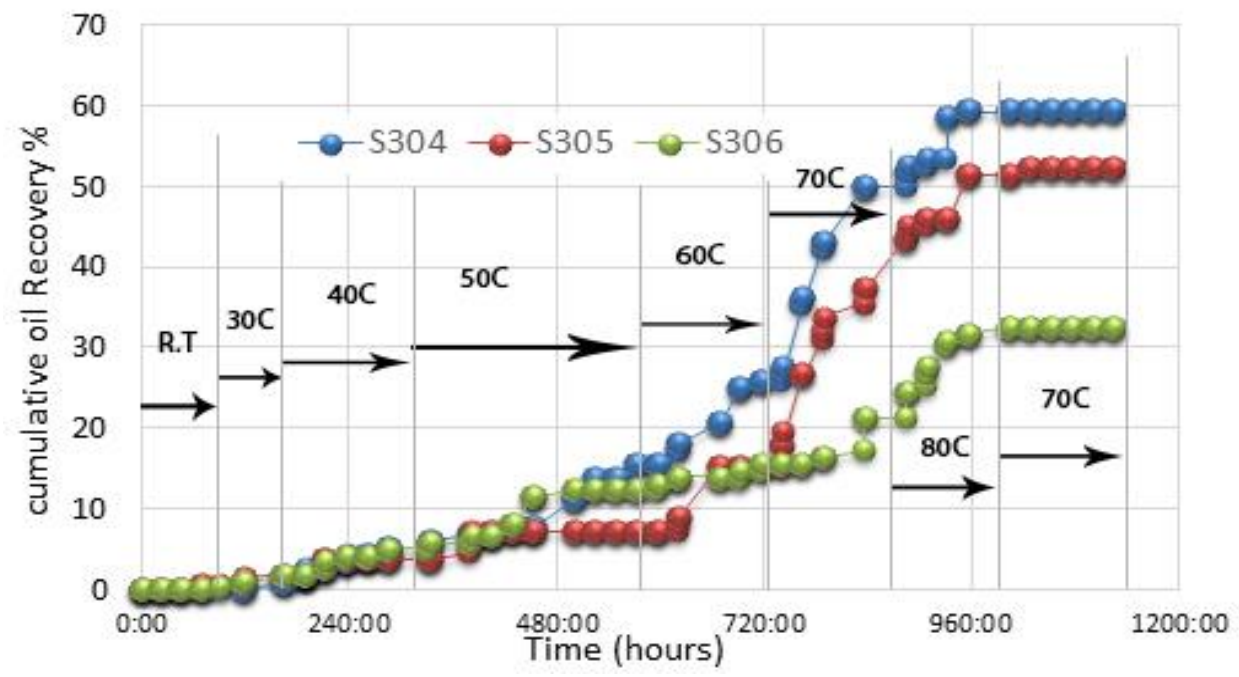

Fig. 4. Cumulative oil recovery in sandstone aged Jakhira Field- GSOP Oil.

Room Temperature $\left(27^{\circ} \mathbf{C}\right)$; At 67 hrs, the oil recovery for S305 was slightly increased to $0.44 \%$, where S304 and S306 was still in zero of production. At $115 \mathrm{hrs}$, the oil recovery for S305 and S306 was increased to $0.44 \%$ and $0.81 \%$, respectively. S304 sample was still in zero of production.

Oven Temperature $\left(\mathbf{3 0}^{\circ} \mathbf{C}\right)$ : At $162 \mathrm{hrs,}$, the oil recovery for S304, S305, and S306 were increased to $0.88 \%$, $1.77 \%$, and $1.62 \%$, respectively.

Oven Temperature $\left(\mathbf{4 0}^{\circ} \mathbf{C}\right)$ : At $210 \mathrm{hrs}$, the oil recovery for S304, S305, and S306 were increased to reach $2.58 \%, 3.54 \%, 2.43 \%$, respectively. At $330 \mathrm{hrs}$, the oil recovery for S304 and S306 were stabled at $4.30 \%$ and $4.86 \%$, respectively. 
Oven Temperature $\left(\mathbf{5 0}^{\circ} \mathbf{C}\right)$ : At 379 hrs, the oil recovery was increased in S304, S305, and S306 to 6.88\%, $4.42 \%$, and $5.67 \%$, respectively. At $571 \mathrm{hrs}$, the oil recovery for S304 was increased to $15.49 \%$ and for S306 to $12.17 \%$, while S305 was still stable.

Oven Temperature $\left(\mathbf{6 0}^{\circ} \mathbf{C}\right)$ : At 618 hrs, the oil recovery for S304, S305, and S306 were increased to $17.21 \%$, $7.08 \%$, and $13.79 \%$, respectively. At $715 \mathrm{hrs}$, the oil recovery of S304, S 305, and S306 was significantly increased to $25.82 \%, 15.05 \%$ and $14.60 \%$, respectively.

Oven Temperature $\left(\mathbf{7 0}^{\circ} \mathbf{C}\right)$; At 763 hrs, the oil recovery was increased to $35.30 \%$ in $\mathrm{S} 304$, and $26.57 \%$ in $\mathrm{S} 305$, and $15.41 \%$ in S306. At $838 \mathrm{hrs,}$, the oil recovery was continued increasing to $49.93 \%$ in S304, and $37.19 \%$ in S305, and 21.09\% in S306. At 126 hrs, the oil recovery was stabled.

Oven Temperature $\left(\mathbf{8 0}^{\circ} \mathbf{C}\right)$; At $907 \mathrm{hrs}$, the oil recovery was increased $52.52 \%$ in $\mathrm{S} 304,45.16 \%$ in $\mathrm{S} 305$, and $25.15 \%$ in S306. At $1003 \mathrm{hrs}$, the oil recovery was increase to $59.40 \%$ in S304, 51.36\% in S305, and $32.45 \%$ in S306.

\section{Carbonate Rock Samples aged in (Hamada Field-V2) Oil Results}

The carbonate rock samples were aged in (Hamada Field- V2) Oil Result as shown in Figure 5.

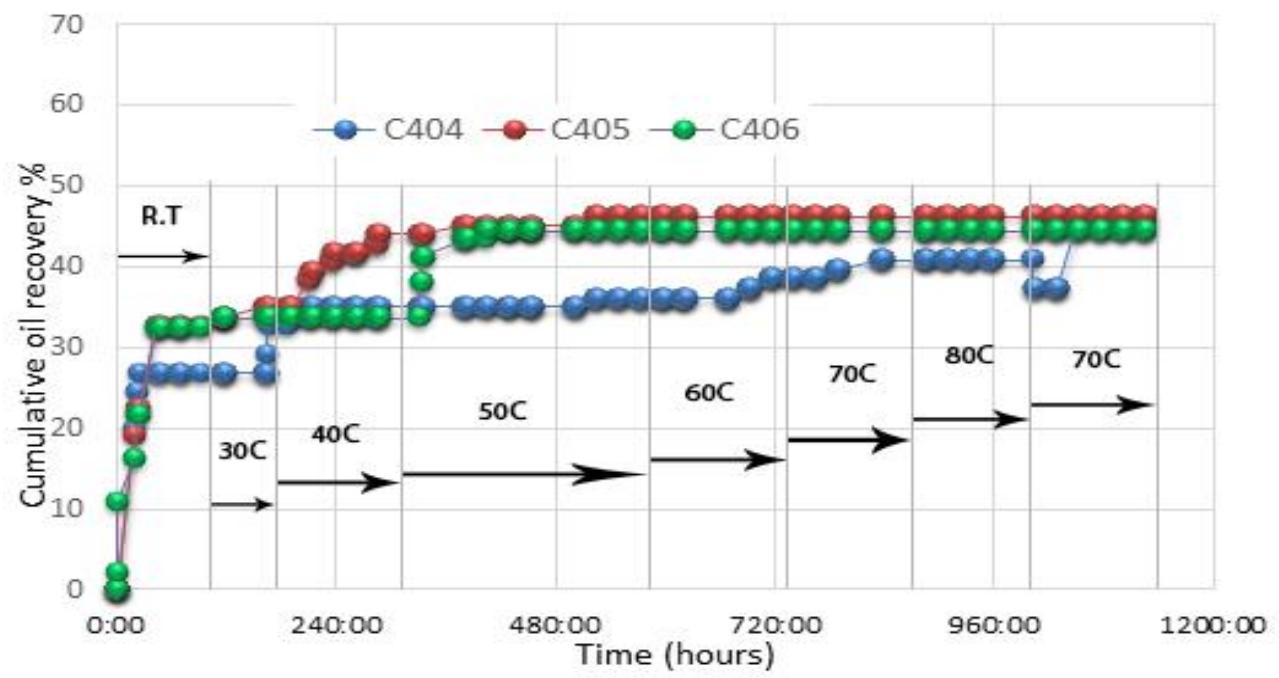

Fig. 5. Cumulative oil recovery in sandstone aged in (Hamada Field-V2) Oil.

Room Temperature $\left(\mathbf{2 7}^{\circ} \mathbf{C}\right)$ : At $30 \mathrm{~min}$, the oil recovery for $\mathrm{C} 406$ was $2.17 \%$. At $19 \mathrm{hrs}$, the oil recovery was reached to $19.87 \%$ in $\mathrm{C} 404,19.20 \%$ in $\mathrm{C} 405$, and $16.32 \%$ in $\mathrm{C} 406$. At 115 hrs, the oil recovery was reached to $26.83 \%$ in $\mathrm{C} 404,33.89 \%$ in $\mathrm{C} 405$, and $33.73 \%$ in $\mathrm{C} 406$.

Oven Temperature $\left(\mathbf{3 0}^{\circ} \mathbf{C}\right)$ : At $166 \mathrm{hrs}$, the oil recovery was increased to $32.74 \%$ in $\mathrm{C} 404,35.02 \%$ in $\mathrm{C} 405$. It was stable in $\mathrm{C} 406$.

Oven Temperature $\left(\mathbf{4 0}^{\circ} \mathbf{C}\right)$; At 210 hrs, the oil recovery was increased to $38.41 \%$ in $\mathrm{C} 405$, and for C404. It was stable in $\mathrm{C} 405$.

Oven Temperature $\left(\mathbf{5 0}^{\circ} \mathbf{C}\right)$ : At $379 \mathrm{hrs}$, the oil recovery was reached to $45.19 \%$ in $\mathrm{C} 405$, and $43.53 \%$ in $\mathrm{C} 406$, and for C404 was stable. At 595 hrs, it was increased to $36.26 \%$ in $\mathrm{C} 404$, and $46.23 \%$ in $\mathrm{C} 405$, and $44.62 \%$ in $\mathrm{C} 406$.

Oven Temperature $\left(\mathbf{6 0}^{\circ} \mathbf{C}\right)$; At 739 hrs, the oil recovery was increased to $38.58 \%$ in $\mathrm{C} 404$. The cores $\mathrm{C} 405$ and C406 were still stable. 
Oven Temperature $\left(\mathbf{7 0}^{\circ} \mathbf{C}\right)$ : At $838 \mathrm{hrs}$, the oil recovery was increased only in $\mathrm{C} 404$ to $40.92 \%$ only, while for C405 and C406 were stable. At 1051 hrs, it was increased in C404 to 45.60\%, while for C405 and C406 were still stable.

Oven Temperature $\left(\mathbf{8 0}^{\circ} \mathbf{C}\right)$ : At 956 hrs, the oil recovery was decreased in $\mathrm{C} 404$ to $37.41 \%$, while in $\mathrm{C} 405$ and C406 were stable.

\section{Sandstone Rock Samples aged in (Hamada Field- V2) Oil Results}

The sandstone rock samples were aged in (Hamada Field- V2) Oil as shown in Figure 6.

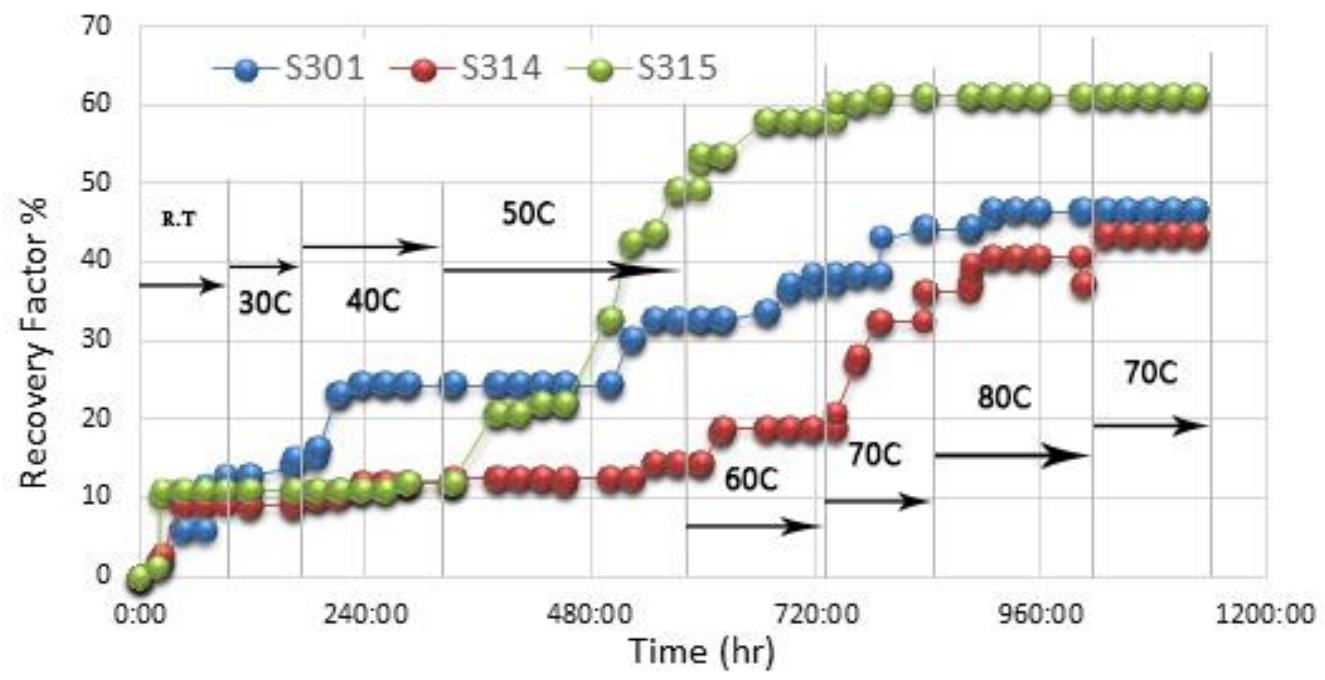

Fig. 6. Cumulative oil recovery in sandstone aged in (Hamada Field- V2) Oil.

Room Temperature $\left(\mathbf{2 7}^{\circ} \mathbf{C}\right)$; At $19 \mathrm{hrs}$, all cores were began to produce oil S301, S314, and S315 to $1.16 \%$, $1.80 \%$, and $1.09 \%$, spontaneously. At $90 \mathrm{hrs}$, the oil recovery was increased to $12.80 \%$ in S301, 9.02\% in $\mathrm{S} 314$, and $10.92 \%$ in $\mathrm{S} 315$.

Oven Temperature $\left(\mathbf{3 0}^{\circ} \mathbf{C}\right)$ : At 166 hrs, the oil recovery in S301 and S314 was increased to $15.13 \%$ in S301, and $9.92 \%$ in S314, while the S315 was still stable.

Oven Temperature $\left(\mathbf{4 0}^{\circ} \mathbf{C}\right)$ : At 212 hrs, the oil recovery was increased in S301 and S314 to $23.29 \%$ and $10.82 \%$, while S315 was stable. At 330 hrs, it was reached in S301, S314, and S315 to $24.45 \%, 11.73 \%$, $12.01 \%$, respectively.

Oven Temperature $\left(\mathbf{5 0}^{\circ} \mathbf{C}\right)$; At 379 hrs, the oil recovery was increased in S301, S314, and S315 to 24.45\%, $12.63 \%$, and $20.75 \%$, respectively. At $523 \mathrm{hrs}$, it was increased gradually to $30.27 \%$ in S301, and $12.63 \%$ in S314, and 42.60\% in S315. At 595 hrs, it was increased to 60\% in S301, and 14.43\% in S314, and $49.16 \%$ in S315.

Oven Temperature $\left(\mathbf{6 0}^{\circ} \mathbf{C}\right)$; At $667 \mathrm{hrs}$, the oil recovery was increased to $33.77 \%$ in S301, and 18.95\% in S314, and $57.90 \%$ in S315. At 739 hrs, the oil recovery was increased to 37.62\% in S301, and $18.95 \%$ in S314, and $57.90 \%$ in $\mathrm{S} 315$.

Oven Temperature ( $\left.\mathbf{7 0}^{\circ} \mathbf{C}\right)$ : At $790 \mathrm{hrs}$, the oil recovery was increased to $43.09 \%$ in S301, and $32.48 \%$ in $\mathrm{S} 314$, and $61.18 \%$ in S315. At 838 hrs, it was increased to $44.25 \%$ in S301, and 36.04\% in S314, and S315 was still stable at $61.18 \%$. At $1028 \mathrm{hrs}$, the oil recovery was reached in S312 to $43.13 \%$.

Oven Temperature $\left(\mathbf{8 0}^{\circ} \mathbf{C}\right)$ : At $908 \mathrm{hrs}$, the oil recovery was increased to $46.58 \%$ in $\mathrm{S} 301$, to $61.18 \%$ in $\mathrm{S} 313$, and to $40.61 \%$ in $\mathrm{S} 312$. 


\section{Carbonate Rock Samples aged in (Hamada Field- V32) Oil Results}

The carbonate rock samples were aged in (Hamada Field- V32) Oil as shown in Figure 7.

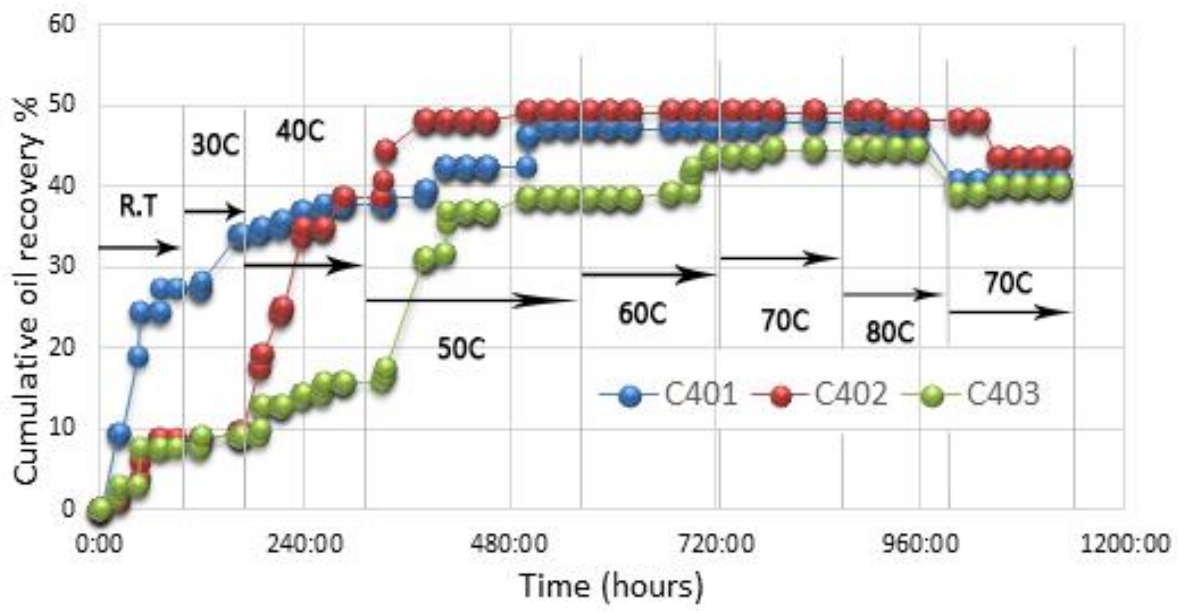

Fig. 7 .Cumulative oil recovery in carbonate aged in (Hamada Field- V32) Oil.

Room Temperature $\left(\mathbf{2 7}^{\circ} \mathbf{C}\right)$; When the aging time is $19 \mathrm{hrs}$, the oil production was began produce and reached to $9.42 \%$ in $\mathrm{C} 401$, to $0.96 \%$ in $\mathrm{C} 402$, and to $1.5 \%$ in $\mathrm{C} 403$. At $46 \mathrm{hrs}$, the oil recovery was significantly increased to $24.51 \%$ in $\mathrm{C} 401$, to $3.86 \%$ in $\mathrm{C} 402$, and to $7.54 \%$ in C403. At 115 hrs, the oil recovery was reached to $27.43 \%$ in $\mathrm{C} 401$, to $8.68 \%$ in $\mathrm{C} 402$, and to $7.54 \%$ in $\mathrm{C} 403$.

Oven Temperature $\left(\mathbf{4 0}^{\circ} \mathbf{C}\right)$ : At $162 \mathrm{hrs}$, the oil recovery was increased to $33.94 \%$ in $\mathrm{C} 401$, to $9.65 \%$ in $\mathrm{C} 402$, and to $9.05 \%$ in $\mathrm{C} 403$.

Oven Temperature $\left(\mathbf{5 0}^{\circ} \mathbf{C}\right)$; At $188 \mathrm{hrs}$, the oil recovery was increased to $34.88 \%$ in $\mathrm{C} 401$, to $19.34 \%$ in $\mathrm{C} 402$, and to $12.83 \%$ in $\mathrm{C} 403$. At $212 \mathrm{hrs}$, the oil recovery was increased regularly to $35.82 \%$ in $\mathrm{C} 401$, to $25.09 \%$ in $\mathrm{C} 402$, to $12.83 \%$ in $\mathrm{C} 403$. At $330 \mathrm{hrs}$, the oil recovery was increased significantly to $37.71 \%$ in $\mathrm{C} 401$, to $38.60 \%$ in $\mathrm{C} 402$, and to $15.82 \%$ in $\mathrm{C} 403$.

Oven Temperature $\left(\mathbf{6 0}^{\circ} \mathbf{C}\right)$; At $335 \mathrm{hrs}$, the oil recovery was increased to $38.65 \%$ in $\mathrm{C} 401$, to $44.40 \%$ in $\mathrm{C} 402$, and to $17.36 \%$ in $\mathrm{C} 403$. At 405 hrs, the oil recovery was increased to $42.42 \%$ in C401, to $48.26 \%$ in C402, and to $35.48 \%$ in C403. At 595 hrs, the oil recovery was increased to $47.14 \%$ in C401, to $49.22 \%$ in $\mathrm{C} 402$, and to $38.50 \%$ in $\mathrm{C} 403$.

Oven Temperature $\left(\mathbf{7 0}^{\circ} \mathbf{C}\right)$; At 787 hrs, the oil recovery was increased to $48.08 \%$ in $\mathrm{C} 401$, to $49.22 \%$ in $\mathrm{C} 402$, and to $44.54 \%$ in C403. At 1051 hrs, the oil recovery in C402 was decrease to $43.43 \%$ and C403 increased to $40.01 \%$, while C401 was stable.

Oven Temperature $\left(\mathbf{8 0}^{\circ} \mathbf{C}\right)$; At 931 hrs, the oil recovery was decrease to $47.14 \%$ in $\mathrm{C} 401$, and $48.26 \%$ in $\mathrm{C} 402$, were in C403 still stable. At $1003 \mathrm{hrs,} \mathrm{the} \mathrm{oil} \mathrm{recovery} \mathrm{was} \mathrm{still} \mathrm{decreased} \mathrm{to} 40.54 \%$ in C401, to $39.25 \%$ in C403, while C402 was still stable.

\section{Sandstone Rock Samples aged in (Hamada Field- V32) Oil Results}

The sandstone rock samples were aged in (Hamada Field- V32) Oil as shown in Figure 8. 


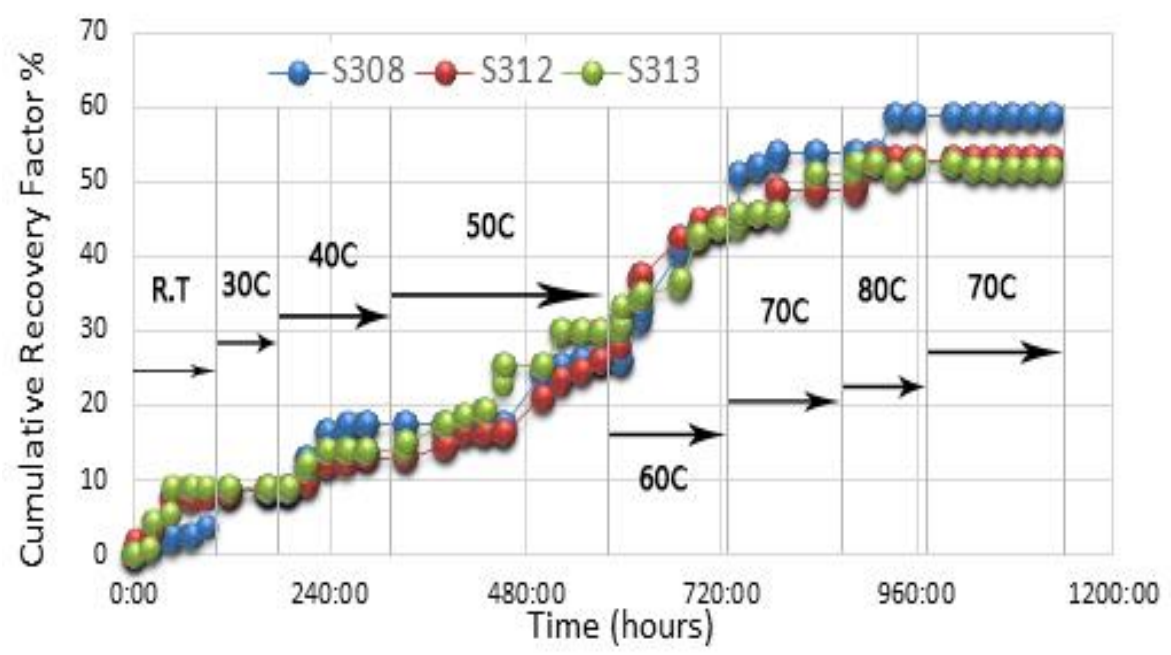

Fig. 8. Cumulative oil recovery in sandstone aged in (Hamada Field- V32) Oil

Room Temperature $\left(\mathbf{2 7}^{\circ} \mathbf{C}\right)$ : At $19 \mathrm{hrs}$, the oil recovery was reached to $0.86 \%$ in $\mathrm{S} 308$, to $1.63 \%$ in $\mathrm{S} 312$, and to $0.87 \%$ in S313. At $115: 43 \mathrm{hrs}$, the oil recovery was increased regularly to $8.67 \%$ in S308, to $8.16 \%$ in $\mathrm{S} 312$, and to $8.76 \%$ in $\mathrm{S} 313$.

Oven Temperature $\left(\mathbf{4 0}^{\circ} \mathbf{C}\right)$ : At 210 hrs, the oil recovery was increased to $13.01 \%$ in $\mathrm{S} 308$, to $9.79 \%$ in $\mathrm{S} 312$, and to $11.40 \%$ in S313. At $330 \mathrm{hrs,}$, the oil recovery was increased to $17.34 \%$ in S308, to $13.06 \%$ in $\mathrm{S} 312$, and to $14.03 \%$ in $\mathrm{S} 313$.

Oven Temperature $\left(\mathbf{5 0}^{\circ} \mathbf{C}\right)$ : At 403 hrs, the oil recovery was increased to $17.34 \%$ in $\mathrm{S} 308$, to $16.32 \%$ in $\mathrm{S} 312$, and to $18.41 \%$ in S313. At 595 hrs, the oil recovery as increased to $26.02 \%$ in S308, to $27.76 \%$ in S312, and to $29.81 \%$ in S313.

Oven Temperature $\left(\mathbf{6 0}^{\circ} \mathbf{C}\right)$; At 618 hrs, the oil recovery was increased to $31.22 \%$ in $\mathrm{S} 308$, to $36.74 \%$ in $\mathrm{S} 312$, and to $34.20 \%$ in $\mathrm{S} 313$. At $739 \mathrm{hrs}$, the oil recovery was increased regularly to $45.10 \%$ in $\mathrm{S} 308$, to $44.90 \%$ in S312, and to $43.84 \%$ in S313.

Oven Temperature $\left(\mathbf{7 0}^{\circ} \mathbf{C}\right)$; At 835 hrs, the oil recovery was increased to $53.77 \%$ in $\mathrm{S} 308$, to $48.98 \%$ in $\mathrm{S} 312$, and to 50.86\% in S313. At $1027 \mathrm{hrs,} \mathrm{the} \mathrm{oil} \mathrm{recovery} \mathrm{was} \mathrm{increased} \mathrm{in} \mathrm{S313} \mathrm{to} \mathrm{51.74 \% ,} \mathrm{while} \mathrm{in} \mathrm{S301}$ and S312 were still stable.

Oven Temperature $\left(\mathbf{8 0}^{\circ} \mathbf{C}\right)$; At 931 hrs, the oil recovery was increased in $\mathrm{S} 301$ to $58.98 \%$, to $53.07 \%$ in $\mathrm{S} 312$, and in S313 was decreased to $50.68 \%$.

\section{Compression between Oil Recoveries (Sandstone Rocks)}

Figure 9 shows compression between oil recoveries with different sandstone core samples. In sandstone core samples (S308, S312, and S313) were aged in Hamada field-V32 oil and the recovery rate was reasonable and approximate. In sandstone core samples (S315, S314, and S301) were aged in Hamada field-V2 oil and the oil recovery was the highest to reach $61.18 \%$. Therefore, the different in oil recovery rate for S315 comparing to S301 and S314 can be due to the higher porosity for S301 and S314. 


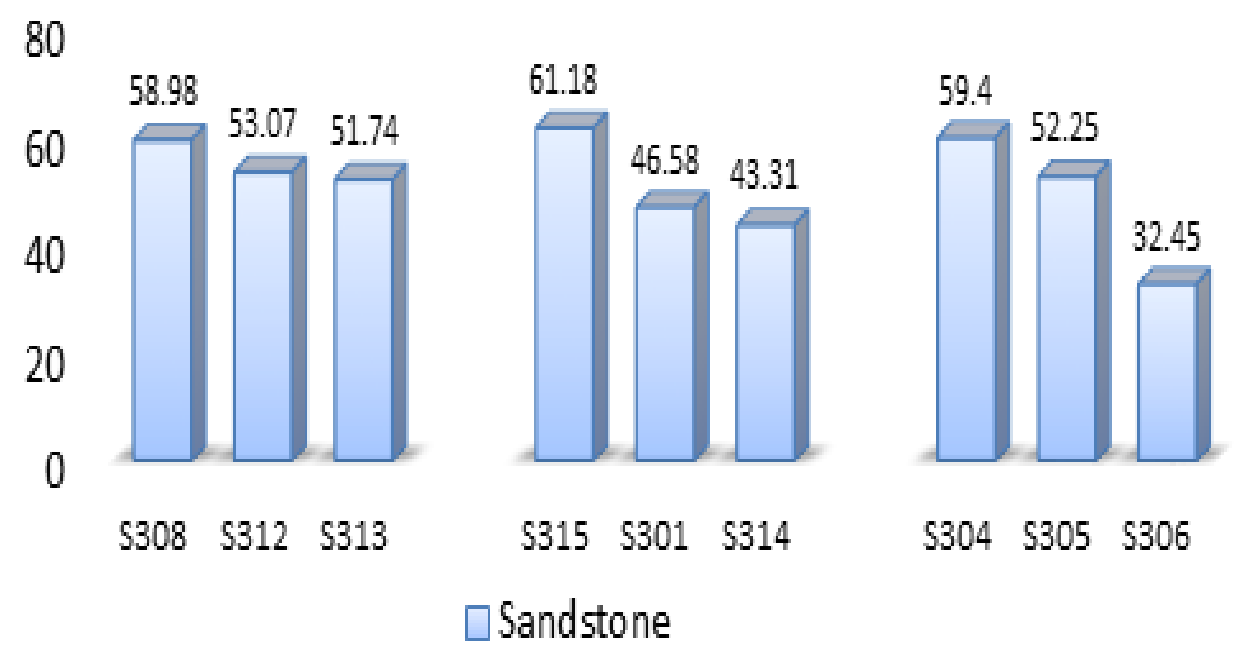

Fig. 9. Compression between oil recoveries with different sandstone core samples.

In sandstone core samples (S304, S305, and S306) were aged in Jakhira field- GSOP oil. The low recovery in S306 could be due to the effect of core plug was caused by permeability reduction. The core plugging and the effect on the permeability of rocks was also reported by Ali and Islam (1998) performed core tests with crude oils from the United Arab Emirates as shown in the figure 10, (Ali and Islam, 1998).

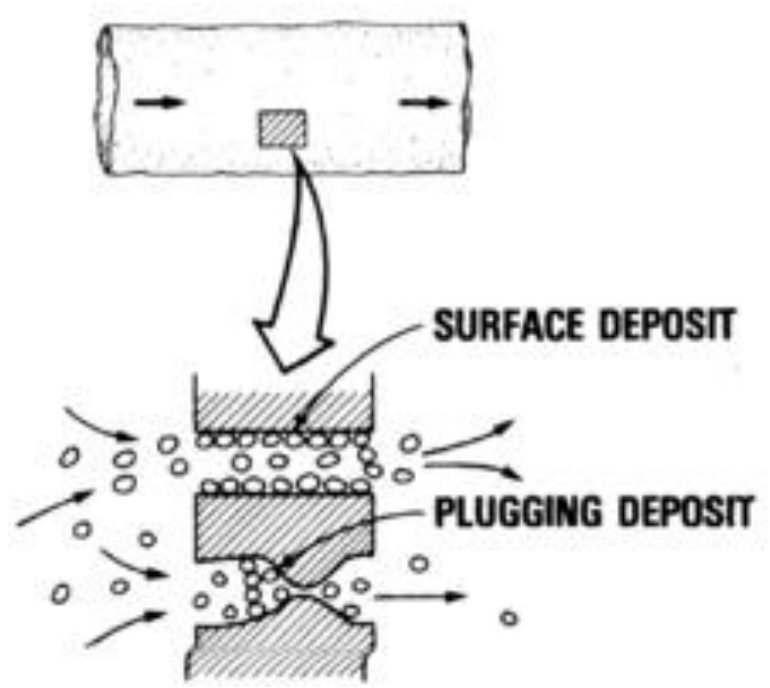

Fig. 10. Core Plugging and Effect on Permeability of Rocks After (Ali and Islam, 1998).

\section{Compression between Oil Recoveries (Carbonate Rocks)}

Figure 11 shows the compression between oil recoveries with different carbonate core samples. In carbonate core samples (C401, C402, and C403) that aged by Hamada field-V32 oil, the oil recovery rate was approximate and reasonable. In carbonate core samples (C404, C405, and C406) were in Hamada field-V2 oil and the oil recovery rate was approximate, and which the effect of temperature and aging time. In carbonate core samples (C408, C410, and C411) were aged in Jakhira field- GSOP oil, the oil recovery rate was very high. This could be to the absorption of the lightest oil during aging process. 


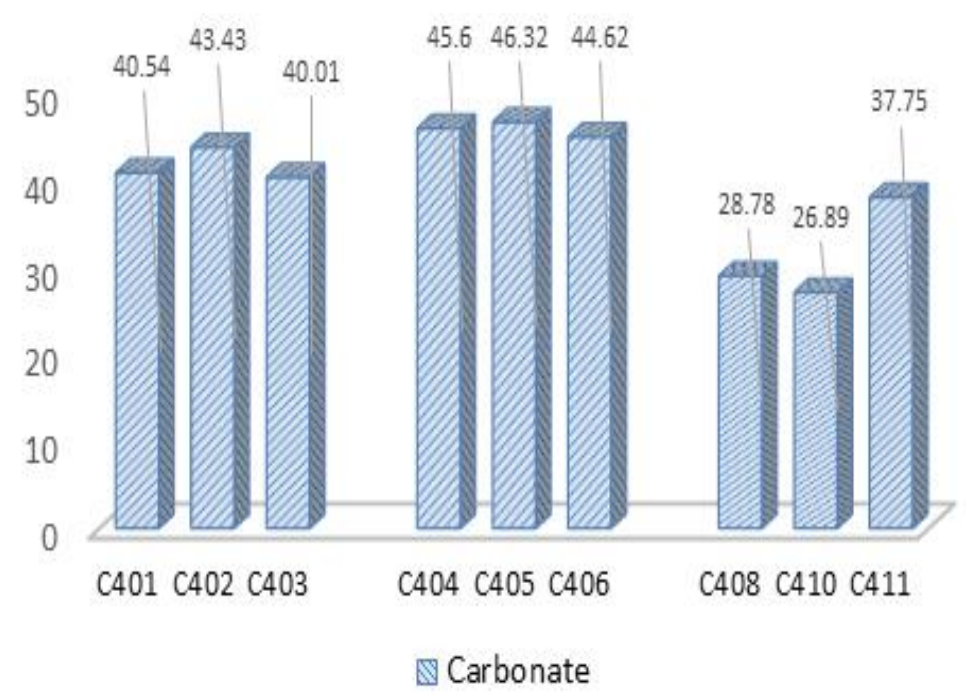

Fig. 11. Compression between oil recoveries with different carbonate core samples.

\section{CONCLUSION}

In this study, the experimentally investigated and visualized the comparison of the effects of sea-water with different crude oils, temperature, and aging time on oil recovery in carbonate and sandstone reservoirs were reported. The experimental setup and procedures were specifically designed to simulate the reservoir conditions. It can be concluded that the impact of seawater on oil recovery in sandstone core samples was higher than carbonate core samples. At higher temperature, the oil recovery was more than at lower temperature. Likewise, increasing the aging time for both sandstone and carbonate core samples, cumulative oil recovery was increased drastically

\section{Acknowledgment}

The authors would like to thank the department of petroleum engineering, faculty of mining and energy and department of chemistry, faculty of science, Sebha University, Libya and petroleum institute in Tripoli, Libya.

\section{References}

Ali, M., and Islam, M., 1998, The effect of asphaltene precipitation on carbonate-rock permeability: an experimental and numerical approach: SPE production \& facilities, v. 13, no. 03, p. 178-183.

Anderson, W., 1987b, Wettability Literature Survey Part 5: The Effects of Wettability on Relative Permeability: SPE-16323-PA.

Anderson, W. G., 1987c, Wettability Literature Survey - Part6: Effect of Wettability on Water-flooding, Volume 39, SPE-16471-PA, p. 18.

Anderson, W. G., 1986a, Wettability Literature Survey- Part 1: Rock/Oil/Brine Interactions and the Effects of Core Handling on Wettability: Journal of Petroleum Technology, v. 38, no. 10, p. 1125-1144.

Anderson, W. G., 1986b, Wettability Literature Survey - Part2: Wettability Measurements: Journal of petroleum technology, v. 38, no. 12, p. 1246-1262.

Anderson, W. G., 1987a, Wettability Literature Survey - Part4: Effect of Wettability on Capillary Pressure: Journal of petroleum technology, v. 39, no. 10, p. 1283-1293.

Bavière, M., 1991, Basic concepts in enhanced oil recovery processes, Springer.

Castor, T., Somerton, W., and Kelly, J., 1981, Recovery mechanisms of alkaline flooding, Surface phenomena in enhanced oil recovery, Springer, p. 249-291.

Cuiec, L., Restoration of the natural state of core samples, in Proceedings Fall Meeting of the Society of Petroleum Engineers of AIME1975, Society of Petroleum Engineers. 
Culec, L., 1977, Study of problems related to the restoration of the natural state of core samples: Journal of Canadian Petroleum Technology, v. 16, no. 04.

Farouq-Ali, S., and Stahl, C., 1970, Increased oil recovery by improved waterflooding: Earth Miner. Sci.;(United States), v. 39, no. 4.

Mungan, N., 1972, Relative permeability measurements using reservoir fluids: Society of Petroleum Engineers Journal, v. 12, no. 05, p. 398-402.

Naser, M. A., 2014, A Laboratory Investigation of the Effects of Temperature, Hardness, Surfactants, and Alkaline on Oil Recovery from Carbonate Reservoirs Using Spontaneous Imbibition Tests: First International Conference on Science and Technology, Tobruk University p. 15.

Naser, M. A., Bae, W., Permad, A. K., and Gunadi, T. A., A Success Story in a Plan of Development Study: Increasing Recovery of Sandstone Reservoir by Water Injection in Indonesia, South Korea, 2013, Sejong University

Schumacher, M., 1978, Enhanced oil recovery. Secondary and tertiary methods.

Tang, G.-Q., and Morrow, N. R., 1999a, Influence of brine composition and fines migration on crude oil/brine/rock interactions and oil recovery: Journal of Petroleum Science and Engineering, v. 24, no. 24, p. 99-111.

Tang, G., and Morrow, N., 1999b, Oil Recovery by Water flooding and Imbibition-Invading Brine Cation Valency and Salinity, paper: SCA-9911.

Tang, G., and Morrow, N. R., 2002, Injection of dilute brine and crude oil/brine/rock interactions: Washington DC American Geophysical Union Geophysical Monograph Series, v. 129, p. 171-179.

Wendell, D., Anderson, W., and Meyers, J., 1987, Restored-State Core Analysis for the Hutton Reservoir: SPE Formation Evaluation, v. 2, no. 04, p. 509-517.

Wissmann, W., Displacement tests with porous rock samples under reservoir conditions, in Proceedings 6th World Petroleum Congress, Frankfurt am Main, Germany, 1963 1963, World Petroleum Congress, p. 16.

Zhang, Y., and Morrow, N. R., Comparison of secondary and tertiary recovery with change in injection brine composition for crude-oil/sandstone combinations, in Proceedings SPE/DOE Symposium on Improved Oil Recovery2006, Society of Petroleum Engineers. 